\title{
O Uso da Fotografia como Prática Humanizadora do Ambiente Hospitalar
}

\author{
Batista, Maria Beatriz de Souza; Portela, Odete Teresinha; Carmagnani, Maria \\ Isabel Sampaio; Luz, Fátima Vicente Ferreira da; Santos, Edson Silva dos; Borgo, \\ Cristiane \\ Hospital São Paulo, Universidade Federal de São Paulo — beatrizbbatista@hotmail.com
}

Introdução: o ambiente de trabalho é constituído por espaços físicos e sociais e, as relações interpessoais são alicerçadas no autoconhecimento e no conhecimento do outro. As imagens fotográficas podem ser mecanismos para a promoção de problematização a cerca do cuidado e do ser cuidado, a partir do trabalhador e do usuário. Ação essa, que implica em uma reflexão crítica e dialógica acerca dos princípios e valores que norteiam a prática dos profissionais, de modo a assumirem a condição de sujeitos e agentes de transformação3. Objetivo: Socializar os resultados do uso de fotografias como atividade de humanização e fortalecimento das relações no ambiente de trabalho. Método: Relato de experiência. a Coordenadora do Grupo de Humanização convidou uma Organização não Governamental para a realização de trabalhos com fotografias junto aos setores de Radioterapia, Plástica, Dermatologia, Reumatologia, Central de Materiais Esterilizados e equipe da limpeza. Foram utilizadas câmeras fotográficas para revelar os olhares dos profissionais sobre o cuidado e o ambiente de trabalho, buscando um olhar mais crítico sobre o mundo que as cerca, criando condições para o desenvolvimento pessoal e social. ao chegar nas unidades, a equipe era apresentada e convidava todos os pacientes e profissionais para participar das atividades. no início, as pessoas pareciam tímidas, receosas em participar, porém logo a timidez era superada com atividades cativantes. com a câmera fotográfica em mãos, os participantes circulavam pelo setor para revelar seus olhares e impressões sobre o cuidar sendo estimulados a refletir sobre "o que significa cuidar". a reflexão partia das imagens, as quais eram legendadas. Resultados: a equipe participou ativamente de todas as atividades propostas refletindo sobre a importância e a valorização do seu trabalho e de profissionais de outros setores do hospital, que trabalham com o mesmo fim, produzir cuidado de qualidade e humanizado ao paciente. As fotos foram expostas em um mural que chamava a atenção de todos que passavam pelas unidades participantes. Conclusão: o uso de fotografias contribuiu para desencadear reflexões sobre a humanização e a importância do ato de cuidar e na melhoria das nas relações entre profissionais, pacientes e familiares. Ainda, despertou em outros profissionais o desejo de participar e conhecer o significado de cuidado humanizado.

Batista, Maria Beatriz de Souza; Portela, Odete Teresinha; Carmagnani, Maria Isabel Sampaio; Luz, Fátima Vicente Ferreira da; Santos, Edson Silva dos; Borgo, Cristiane. O Uso da Fotografia como Prática Humanizadora do Ambiente Hospitalar. In: Anais do Congresso Internacional de Humanidades \& Humanização em Saúde [= Blucher Medical Proceedings, num.2, vol.1]. São Paulo: Editora Blucher, 2014. ISSN 2357-7282

DOI 10.5151/medpro-cihhs-10505 